CZASOPISMO INŻYNIERII LĄDOWEJ, ŚRODOWISKA I ARCHITEKTURY JOURNAL OF CIVIL ENGINEERING, ENVIRONMENT AND ARCHITECTURE

JCEEA, t. XXXIV, z. 64 (2/I/17), kwiecien-czerwiec 2017, s. 227-238, DOI:10.7862/rb.2017.67

\author{
Tomasz SIWOWSKI ${ }^{1}$ \\ Mateusz RAJCHEL ${ }^{2}$ \\ Damian KALETA ${ }^{3}$
}

\title{
CHARAKTERYSTYKA DYNAMICZNA MOSTU DROGOWEGO WYKONANEGO Z POLIMEROWYCH KOMPOZYTÓW WŁÓKNISTYCH FRP
}

\begin{abstract}
Przęsło kompozytowe mostu drogowego ma zazwyczaj wysoki stosunek obciążeń ruchomych do stałych (ciężaru własnego), co czyni je znacznie bardziej wrażliwym na oddziaływanie poruszających się pojazdów niż mosty konwencjonalne ze stali i betonu. To m.in. powoduje, że charakterystyka dynamiczna przęseł mostów kompozytowych jest obecnie jednym z najważniejszych aspektów, koniecznych do analizy w procesie projektowania, budowy i eksploatacji mostów kompozytowych. $\mathrm{W}$ badaniach dynamicznych obiektu mostowego jego charakterystykę otrzymuje się zazwyczaj z bezpośredniego pomiaru przyśpieszeń, odkształceń lub przemieszczeń określonych punktów konstrukcji, wymuszonych w czasie rzeczywistym przez poruszające się po nim z różną prędkością pojazdy. Ta metoda została zastosowana również w badaniach pierwszego polskiego mostu drogowego, którego zarówno dźwigary główne jak i płytę pomostu wykonano z kompozytów FRP. Na podstawie pomiarów przemieszczeń wybranych punktów przęsła pod wpływem obciążenia przejeżdżającymi pojazdami wyznaczono podstawowe charakterystyki dynamiczne mostu: współczynniki dynamiczne, częstości drgań własnych oraz współczynnik tłumienia. Otrzymane wartości potwierdziły właściwe parametry dynamiczne mostu kompozytowego w świetle wymagań stawianych drogowym obiektom mostowym w Polsce.
\end{abstract}

Słowa kluczowe: współczynnik dynamiczny, częstość drgań własnych, współczynnik tłumienia, przęsło mostu, kompozyt FRP, badania mostu

\footnotetext{
${ }^{1}$ Autor do korespondencji / corresponding author: Tomasz Siwowski, Politechnika Rzeszowska, Zakład Dróg i Mostów, ul. Poznańska 2, 35-959 Rzeszów; tel. 178651926; siwowski@ prz.edu.pl

2 Mateusz Rajchel, Politechnika Rzeszowska, Zakład Dróg i Mostów, ul. Poznańska 2, 35-959 Rzeszów; tel. 178651016; mrajchel@prz.edu.pl

${ }^{3}$ Damian Kaleta, Promost Consulting Sp. z o.o. Sp.k., ul. Bohaterów 10 Sudeckiej Dywizji Piechoty 4, 35-307 Rzeszów; tel. 178579155; kaleta@ promost.pl
} 


\section{Wprowadzenie}

Pierwsza dekada XXI w. przyniosła znaczące upowszechnienie w budownictwie mostowym nowego materiału konstrukcyjnego, jakim są kompozyty włókniste FRP (ang. fibre reinforced polymers). Kompozyty włókniste to materiały powstałe $\mathrm{z}$ połączenia włókien syntetycznych (węglowych, szklanych, aramidowych, bazaltowych) oraz polimerów (np. żywicy epoksydowej, poliestrowej, winyloestrowej). Charakteryzują się one zdecydowanie lepszymi własnościami fizycznymi i mechanicznymi beton, stal czy niż drewno, tradycyjne materiały budowlane stosowane $\mathrm{w}$ mostownictwie. Z konstrukcyjnego punktu widzenia do największych zalet kompozytów FRP należą m.in.: wysoka wytrzymałość, doskonała trwałość, duża sztywność (w przypadku kompozytu z włókien węglowych) oraz mała masa konstrukcji, a co za tym idzie łatwość i szybkość jej wznoszenia. Jednakże z drugiej strony lekkość konstrukcji kompozytowej wymaga, aby przy jej kształtowaniu i projektowaniu odpowiednią wagę przykładać do jej parametrów dynamicznych.

Przęsło kompozytowe mostu drogowego ma zazwyczaj wysoki stosunek obciążeń ruchomych do stałych (ciężaru własnego), co czyni je znacznie bardziej wrażliwym na oddziaływanie poruszających się pojazdów niż przęsła mostów konwencjonalnych. Co więcej, mały ciężar konstrukcji w połączeniu z niższym (np. od betonu) tłumieniem materiałowym kompozytu FRP, może prowadzić do nadmiernych drgań oraz wzrostu poziomu odkształceń i przemieszczeń przęsła wskutek oddziaływań dynamicznych pojazdów. Np. badania kilku amerykańskich mostów kompozytowych wykazały, że tzw. współczynnik dynamiczny dla tych mostów wahał się, w zależności od prędkości i rodzaju pojazdów wymuszających, od 1,71 do 1,93 przy projektowej wartości dopuszczalnej 1,33 [1], [2]. Te cechy mostów kompozytowych powodują, że ich charakterystyka dynamiczna jest jednym z najważniejszych aspektów, koniecznych do analizy w procesie ich projektowania. Drugim ważnym powodem, dla którego ocena parametrów dynamicznych mostów kompozytowych jest bardzo istotna jest fakt, że służy ona jako efektywny sposób identyfikacji zmiany stanu technicznego mostu w czasie. Przy braku sprawdzonych procedur utrzymania i monitoringu stanu mostów kompozytowych, właśnie zmiana charakterystyk dynamicznych konstrukcji, oceniana w określonym przedziale czasowym w jej cyklu życia, jest niezawodnym sposobem identyfikacji zmian konstrukcyjnych.

W badaniach dynamicznych obiektu mostowego jego charakterystykę otrzymuje się zazwyczaj z bezpośredniego pomiaru przyśpieszeń, odkształceń lub przemieszczeń określonych punktów konstrukcji, wymuszonych w czasie rzeczywistym przez poruszające się po nim z różną prędkością pojazdy. Większość znanych z piśmiennictwa charakterystyk dynamicznych mostów kompozytowych została wyznaczona na podstawie obróbki pomiarów, zazwyczaj w dziedzinie częstotliwości [1], [3], [4], [5]. Ta metoda została zastosowana również w badaniach pierwszego polskiego mostu drogowego, którego zarówno dźwiga- 
ry główne jak i płytę pomostu wykonano z kompozytów FRP. Na podstawie pomiarów przemieszczeń wyznaczono podstawowe charakterystyki dynamiczne przęsła mostu: współczynniki dynamiczne, częstotliwości drgań własnych oraz współczynnik tłumienia. Otrzymane wartości pozwoliły na weryfikację modelu numerycznego konstrukcji, użytego do jej zaprojektowania, a także potwierdziły jej właściwe parametry dynamiczne w świetle wymagań stawianych drogowym obiektom mostowym w Polsce.

\section{Opis mostu drogowego z kompozytów FRP}

Pierwszy w Polsce most drogowy, którego przęsło wykonano w całości z kompozytów FRP, został zbudowany w miejscowości Nowa Wieś koło Rzeszowa. Most jest położony w ciągu drogi powiatowej i przekracza niewielki potok Czarna. Jest obiektem jednoprzęsłowym, swobodnie podpartym, położonym zgodnie z niweletą i krzywizną drogi w spadku podłużnym $2,1 \%$ i jednostronnym spadku poprzecznym 3\%. Główne parametry techniczne mostu są następujące: rozpiętość teoretyczna przęsła - 10,0 m; długość całkowita pomostu $-10,7 \mathrm{~m}$; całkowita szerokość mostu - 7,7 m; szerokości użytkowe: jezdnia $-5 \mathrm{~m}(2 \times 2,5 \mathrm{~m})$, opaska bezpieczeństwa $-2 \times 0,5 \mathrm{~m}$; chodnik $-0,75 \div 1,1 \mathrm{~m}$; balustrada z gzymsem $-2 \mathrm{x} 0,25$ m. Most ma nośność 30 ton (rys. 1).

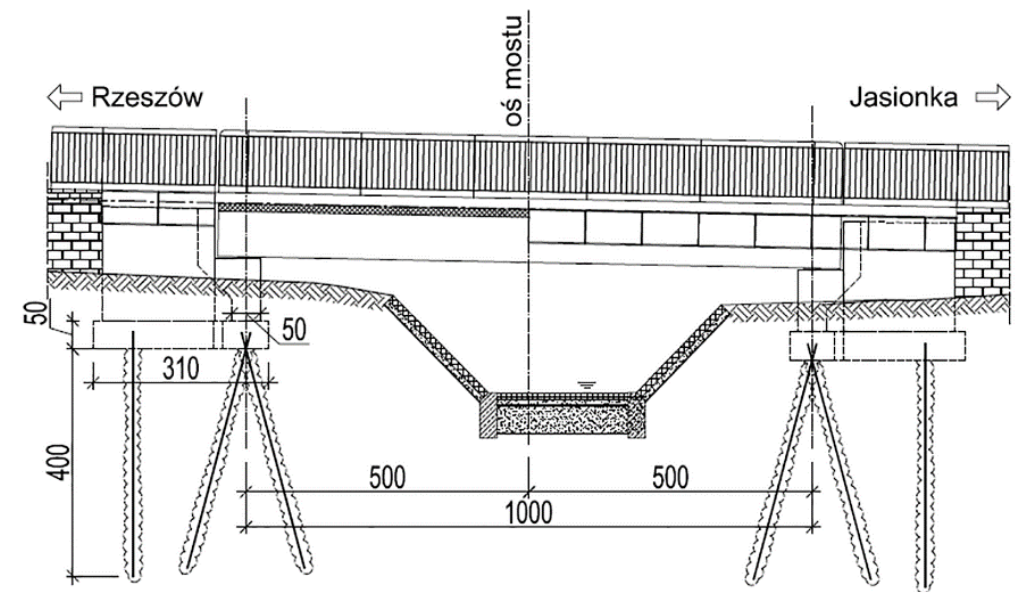

Rys. 1. Widok ogólny mostu kompozytowego w Nowej Wsi

Fig. 1. General view of the FRP composite bridge in Nowa Wies

Przęsło mostu jest wykonane z czterech dźwigarów kompozytowych o przekroju skrzynkowym (typu U) w rozstawie osiowym 1,9 m oraz zespolonej z dźwigarami warstwowej płyty pomostu (rys. 2). Dźwigary główne mają następujące wymiary: wysokość $-0,715 \mathrm{~m}$, szerokość w poziomie pasa górnego - 1,38 m oraz szerokość w poziomie pasa dolnego - 0,60 m. Nominalna grubość laminatów pasa 
górnego i dolnego wynosi $15 \mathrm{~mm}$. Środniki dźwigarów są kompozytem warstwowym, składającym się z dwóch zewnętrznych laminatów oraz przekładki z pianki PUR. Grubość całkowita środników wynosi 17 mm. Wnętrze przekrojów skrzynkowych dźwigarów usztywniono przeponami o budowie analogicznej jak środnik i grubości $46 \mathrm{~mm}$ w rozstawie $1,25 \mathrm{~m}$. Wszystkie laminaty dźwigarów wykonano w całości z kompozytu na bazie włókien szklanych i żywicy epoksydowej.

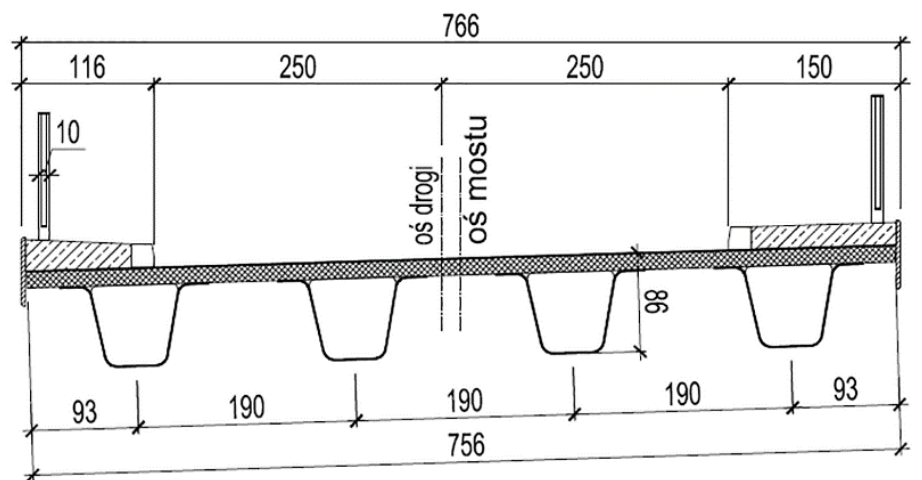

Rys. 2. Przekrój poprzeczny przęsła mostu kompozytowego

Fig. 2. Cross-section of the FRP composite superstructure

Kompozytowa płyta pomostu ma grubość 0,135 m, szerokość 7,56 m i długość $10,7 \mathrm{~m}$. Płyta jest kompozytem warstwowym typu sandwich, składającym się z dwóch zewnętrznych laminatów o grubości 11,5 mm każdy oraz przekładki z pianki PUR o wysokości $105 \mathrm{~mm}$ i grubości $25 \mathrm{~mm}$, usztywnionej kompozytowymi żebrami wewnętrznymi w postaci laminatów o grubości ok. $1 \mathrm{~mm}$. Na szerokości $1 \mathrm{mb}$ panelu płyty pomostu znajduje się 37 wewnętrznych żeber kompozytowych. Płytę w całości wykonano z kompozytu z włókien szklanych i żywicy epoksydowej. Ze względów transportowych przęsło zostało podzielone po szerokości na trzy części: dwa identyczne tandemy (po 2 dźwigary i odpowiadający im fragment płyty) oraz środkowy, płytowy element scalający. Połączenia podłużne przęsła zlokalizowano w miejscu występowania najmniejszych sił wewnętrznych w płycie, tuż nad pasami górnymi dźwigarów wewnętrznych. Połączenia te wykonywane na budowie. Ograniczenia w procesie wytwarzania elementów montażowych płyty wymusiły jej dodatkowy podział na długości przęsła. Styki poprzeczne płyty wykonano w warsztacie. Wszystkie połączenia w kompozytowym przęśle mostu, tj.: styki płyty pomostu, styki przepon wewnętrznych oraz zespolenie ,dźwigary - płyta”, wykonano jako klejone za pomocą kleju na bazie żywicy epoksydowej.

$\mathrm{Na}$ kompozytowej płycie pomostu zostały wykonane kapy chodnikowe grubości od 0,15 do $0,18 \mathrm{~m}$, ograniczone od strony jezdni krawężnikami kamiennymi natomiast od strony zewnętrznej deskami gzymsowymi z polimerobe- 
tonu. Kapy chodnikowe wykonano z betonu lekkiego LC30/33, zbrojnego prętami kompozytowymi z włókien szklanych i żywicy poliestrowej. Od strony zewnętrznych krawędzi pomostu zamontowano stalowe balustrady systemowe o wysokości $1,1 \mathrm{~m}$. Przyczółki mostu posadowiono na mikropalach o średnicy $110 \mathrm{~mm}$ i długości 4,0 m i zatopiono w nasypach dojazdów, które ze względu na ograniczenia terenowe są częściowo umocnione murami oporowymi.

\section{Schemat badań dynamicznych mostu}

Do identyfikacji parametrów dynamicznych mostu zastosowano pomiar przemieszczeń pionowych dźwigarów i płyty pomostu w środku rozpiętości przęsła (rys. 3). Rejestrowano czasowe zmiany wartości przemieszczeń za pomocą czujników indukcyjnych o bazie pomiarowej $50 \mathrm{~mm}$ i dokładności odczytu $0,01 \mathrm{~mm}$, zlokalizowanych $\mathrm{w}$ sześciu punktach pomiarowych $\mathrm{w}$ środku rozpiętości przęsła: czterech pasach dolnych dźwigarów oraz wspornikach płyty pomostu (rys. 4).

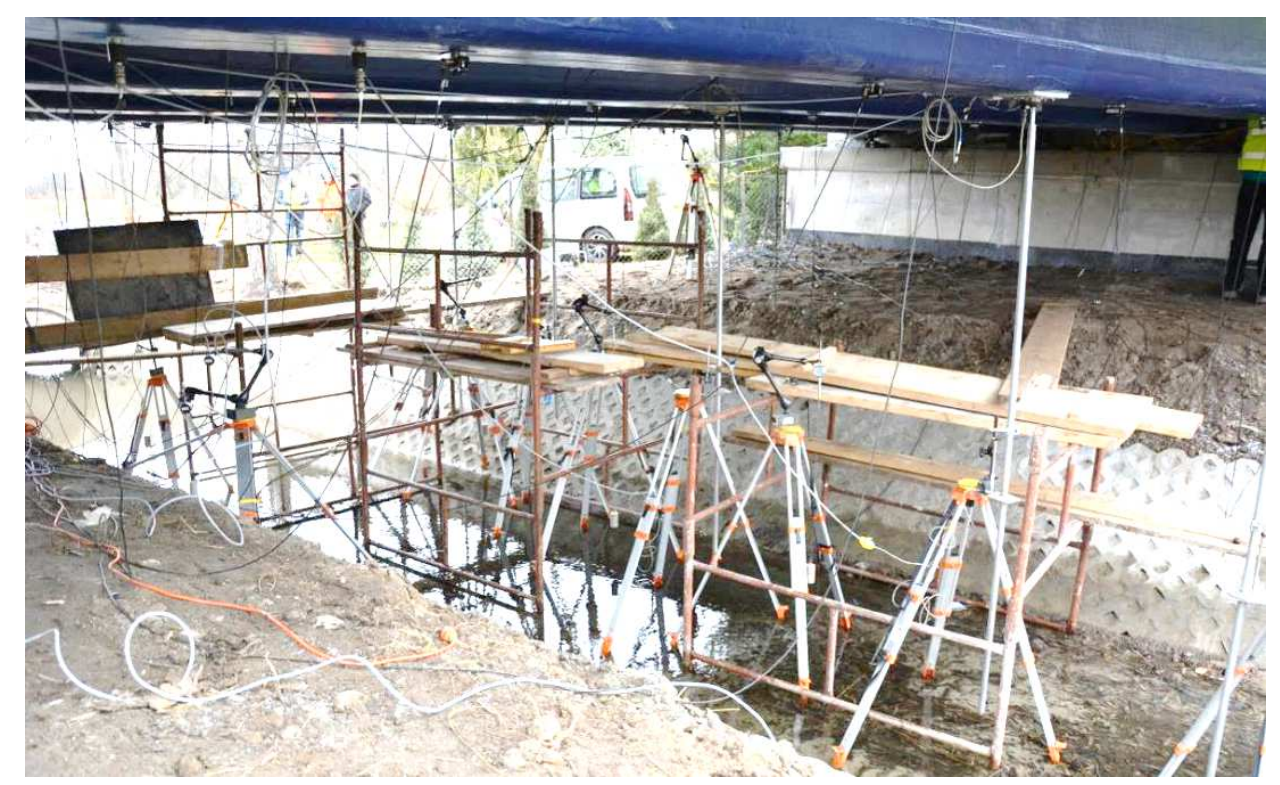

Rys. 3. Stanowisko pomiaru przemieszczeń pionowych dźwigarów

Fig. 3. Set-up of vertical displacement measurement

Obciążenie dynamiczne mostu zrealizowano za pomocą samochodu ciężarowego o masie z ładunkiem około 32 tony (rys. 5). Do oceny efektów dynamicznych zastosowano 5 schematów badawczych (S1 - S5):

- $\mathrm{S} 1$ - przejazd samochodu z prędkością $10 \mathrm{~km} / \mathrm{h}$,

- S2 - przejazd samochodu z prędkością $20 \mathrm{~km} / \mathrm{h}$, 
- S3 - przejazd samochodu z prędkością $25 \mathrm{~km} / \mathrm{h}$,

- $\mathrm{S} 4$ - przejazd samochodu z prędkością $15 \mathrm{~km} / \mathrm{h}$ z hamowaniem na moście,

- S5 - przejazd samochodu z prędkością $10 \mathrm{~km} / \mathrm{h}$ przez próg.

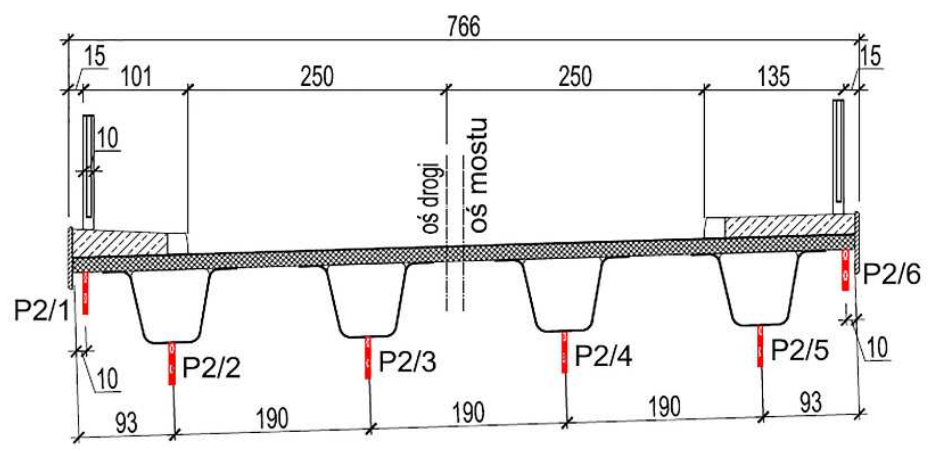

Rys. 4. Lokalizacja punktów pomiaru przemieszczeń przęsła

Fig. 4. Measurement points of span vertical displacements

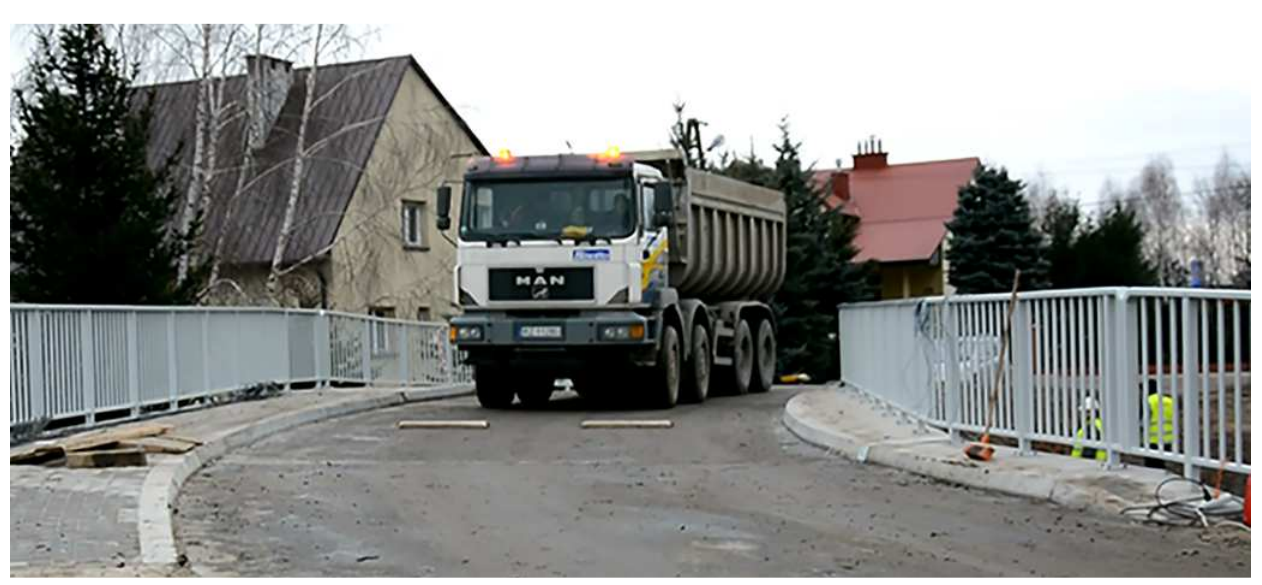

Rys. 5. Przejazd samochodu przez most (schemat S5)

Fig. 5. Vehicle passing through the bridge (S5 scheme)

\section{Wyniki badań dynamicznych mostu i ich analiza}

Wybrane wyniki pomiarów przemieszczeń w czasie przejazdu samochodów w poszczególnych schematach obciążenia przedstawiono na rys. 6-13.

Analiza wyników badań mostu pod obciążeniem dynamicznym polegała na wyznaczeniu tzw. współczynnika dynamicznego, pierwszych częstotliwości drgań własnych oraz logarytmicznego dekrementu tłumienia (współczynnika tłumienia) dla kompozytowego przęsła mostu. 
Współczynniki dynamiczne wyznaczono jako stosunek maksymalnego ugięcia dynamicznego, (największa wartość na wykresie ugięcia w funkcji czasu) do maksymalnego ugięcia statycznego (średnia z minimalnej i maksymalnej wartości na wykresie) wg wzoru (1):

$$
\varphi=\frac{f_{d y n}}{f_{s t}}
$$

gdzie: $\varphi$ - współczynnik dynamiczny,

$f_{d y n}$ - ugięcie dynamiczne,

$f_{s t}$ - ugięcie statyczne.

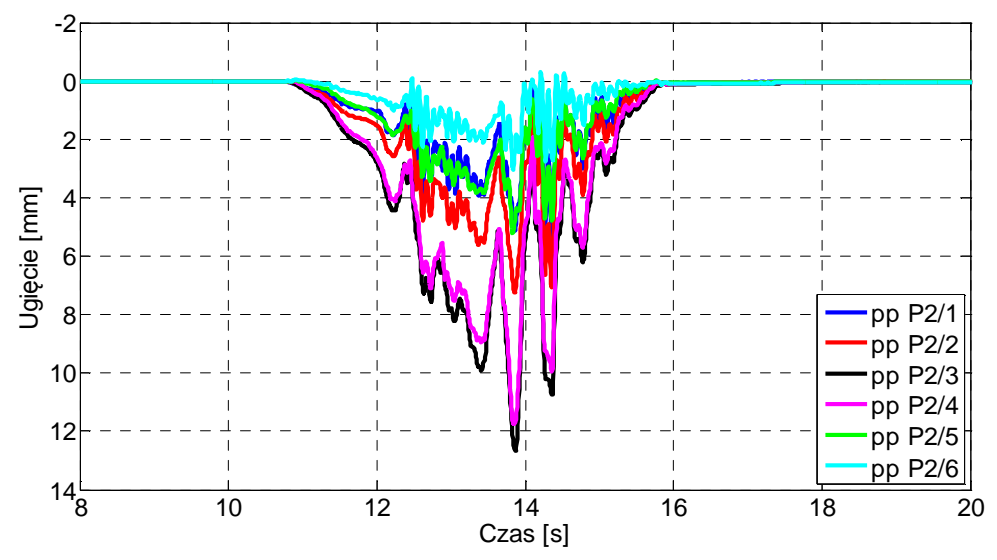

Rys. 6. Ugięcia w sześciu punktach pomiarowych w schemacie $\mathrm{S} 1$

Fig. 6. Deflections in six measurement points of $\mathrm{S} 1$ scheme

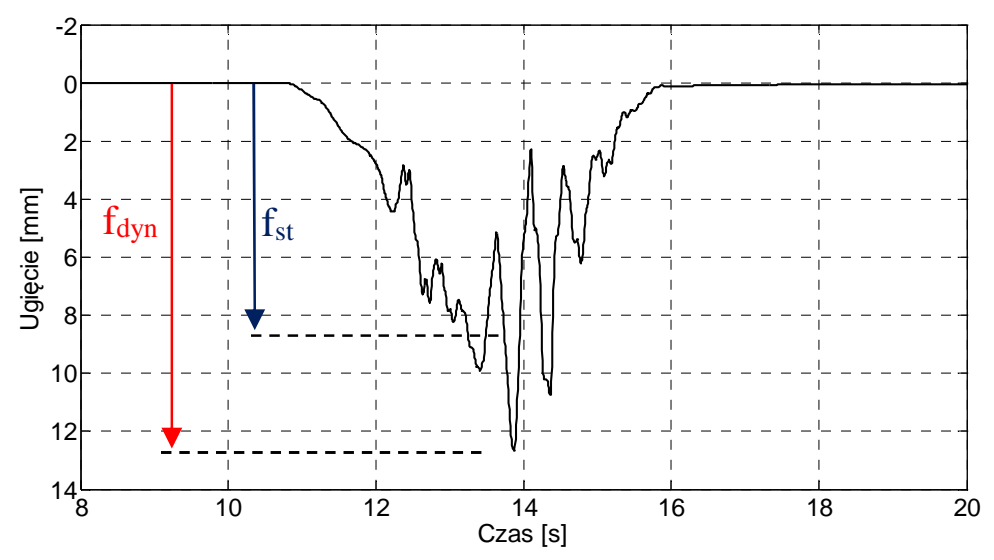

Rys. 7. Maksymalne ugięcie w punkcie pomiarowym P2/3 w schemacie S1

Fig. 7. Maximum deflection in $\mathrm{P} 2 / 3$ measurement point in $\mathrm{S} 1$ scheme 


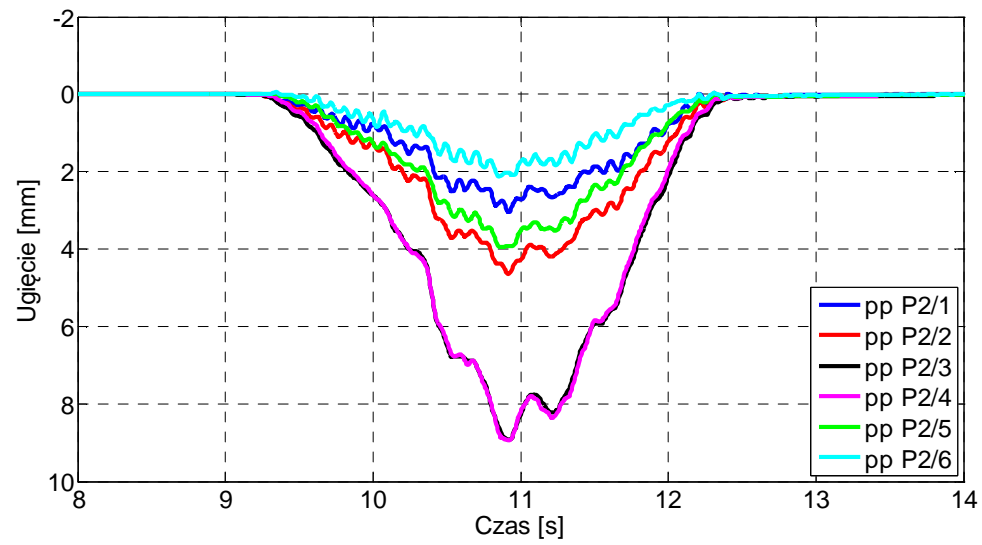

Rys. 8. Ugięcie w sześciu punktach pomiarowych w schemacie S2

Fig. 8. Deflections in six measurement points of S2 scheme

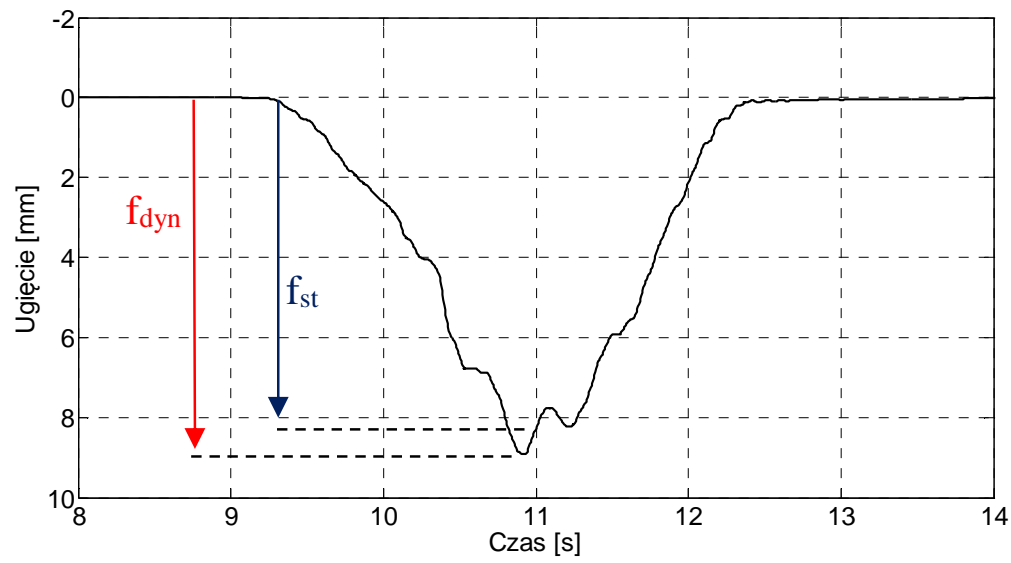

Rys. 9. Maksymalne ugięcie w punkcie pomiarowym P2/3 w schemacie S2

Fig. 9. Maximum deflection in $\mathrm{P} 2 / 3$ measurement point in $\mathrm{S} 2$ scheme

Tabela 1. Maksymalne wartości współczynnika dynamicznego w schematach obciążenia Table 1. Maximum values of dynamic coefficients in loading schemes

\begin{tabular}{|c|c|c|c|}
\hline Schemat obciążenia & S1 & S2 & S3 \\
\hline Prędkość przejazdu $[\mathrm{km} / \mathrm{h}]$ & 10 & 20 & 25 \\
\hline Współczynnik dynamiczny & 1,079 & 1,100 & 1,102 \\
\hline
\end{tabular}

Maksymalne wartości współczynnika dynamicznego dla poszczególnych schematów obciążenia podano w tabeli 1 . Żadna z tych wartości nie przekroczyła wartości normowej [6], wynoszącej $\varphi=1,25$ i przyjętej w obliczeniach podczas projektowania mostu. 


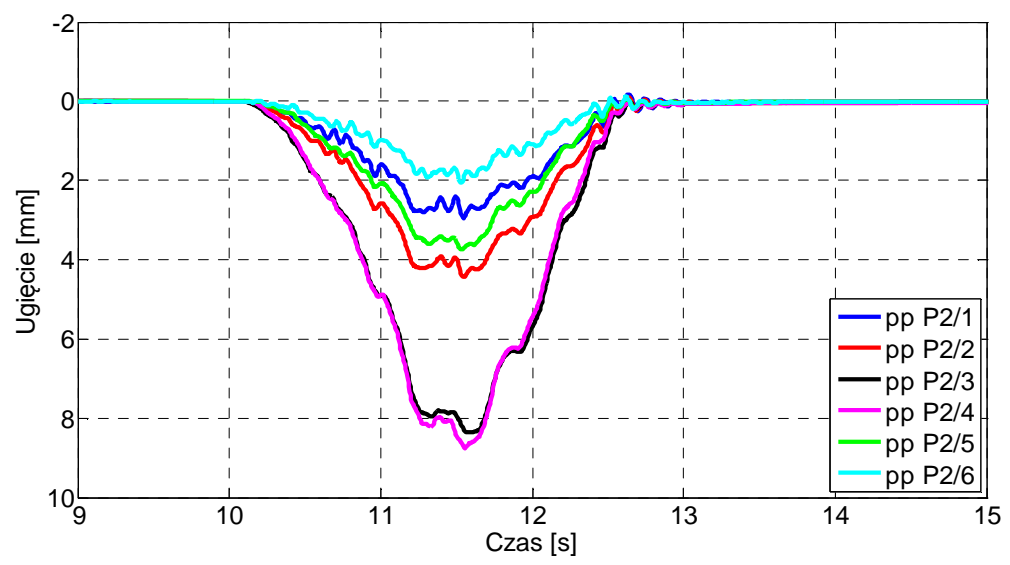

Rys. 10. Ugięcie w sześciu punktach pomiarowych w schemacie S3

Fig. 10. Deflections in six measurement points of S3 scheme

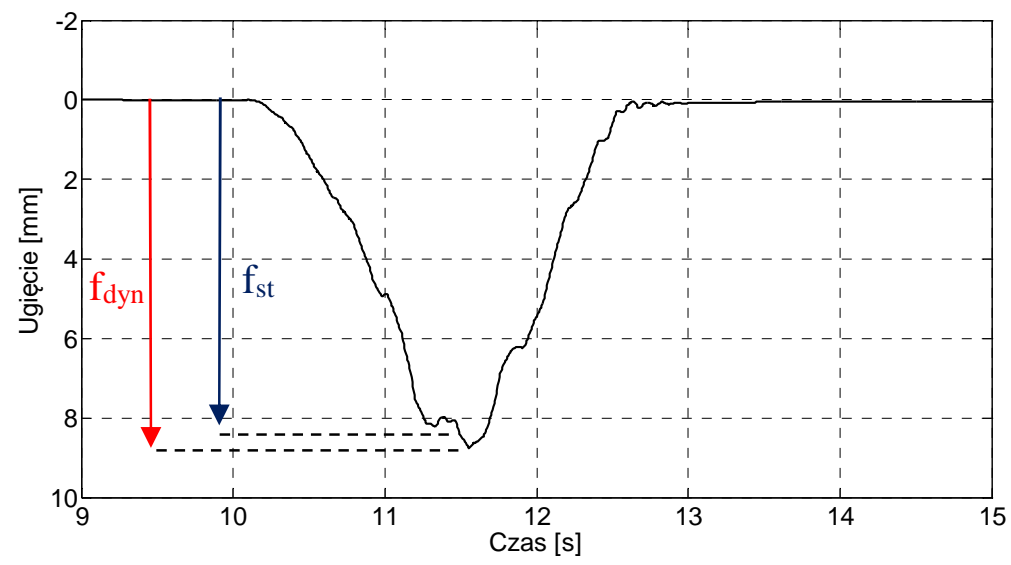

Rys. 11. Maksymalne ugięcie w punkcie pomiarowym P2/4 w schemacie S3

Fig. 11. Maximum deflection in $\mathrm{P} 2 / 3$ measurement point in S3 scheme

Częstotliwość drgań własnych przęsła została wyznaczona na podstawie wykresów drgań mostu uzyskanych podczas przejazdu samochodu z prędkością $25 \mathrm{~km} / \mathrm{h}$ (schemat S3) oraz przejazdu przez próg i podczas hamowania na moście (schematy S4, S5). Częstotliwość drgań własnych przęsła mostu, zmierzonych tuż po opuszczeniu przęsła przez pojazd, została wyznaczona wg wzoru (2):

$$
\eta=\frac{n}{t_{s}}=\frac{1}{T}
$$

gdzie: $n$ - liczba drgań w czasie $t_{s}$ policzona na wykresie drgań konstrukcji, $T$ - okres drgań własnych konstrukcji. 


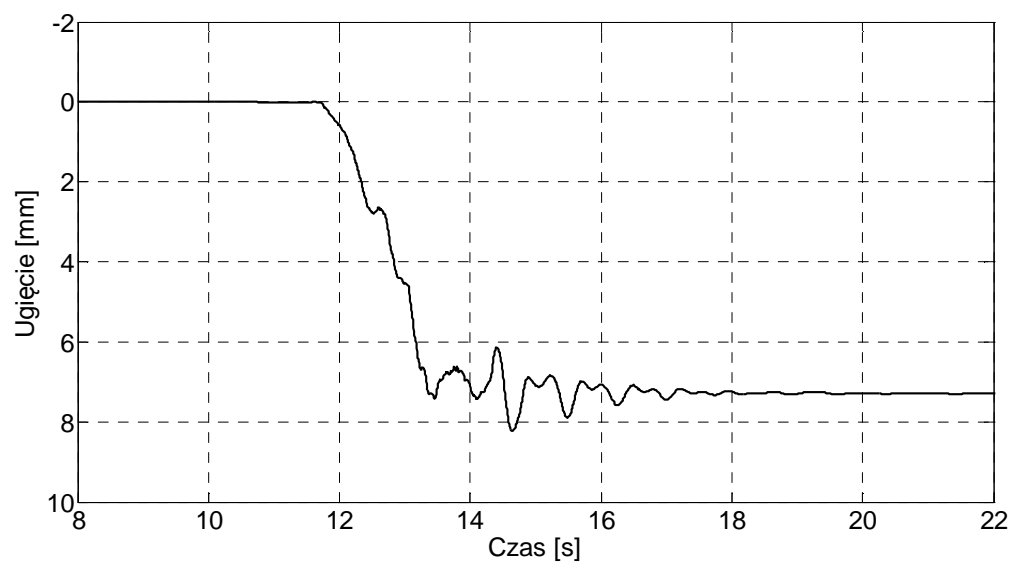

Rys. 12. Maksymalne ugięcie w punkcie pomiarowym P2/4 w schemacie S4

Fig. 12. Maximum deflection in $\mathrm{P} 2 / 4$ measurement point in $\mathrm{S} 4$ scheme

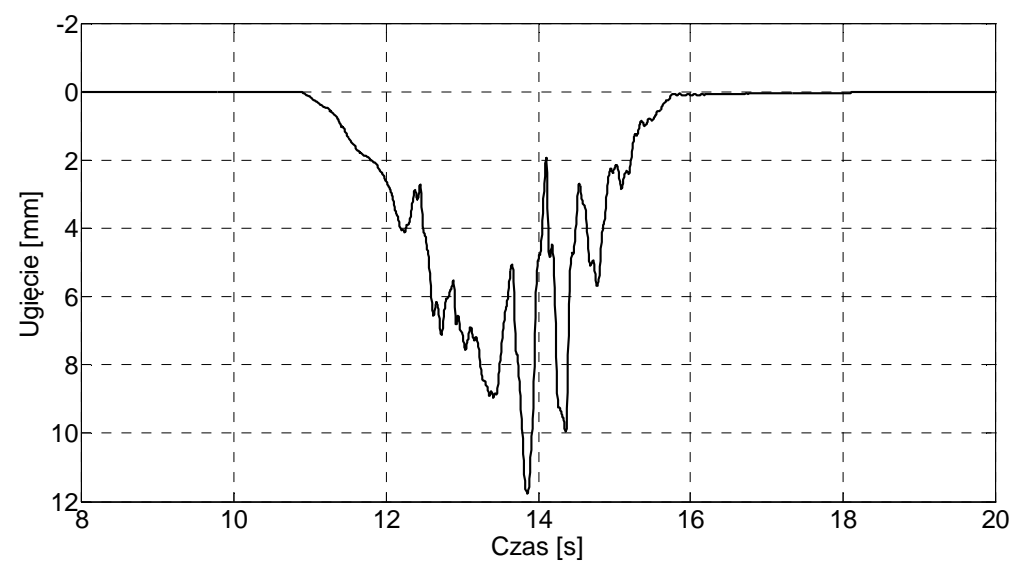

Rys. 13. Maksymalne ugięcie w punkcie pomiarowym P2/4 w schemacie S5

Fig. 13. Maximum deflection in P2/4 measurement point in S5 scheme

Wyznaczona w opisany sposób podstawowa częstotliwość drgań własnych (giętych) przęsła wyniosła 10,1 Hz. Częstotliwość ta jest ponad 3-krotnie większa od minimalnej wartości dopuszczalnej w rozporządzeniu [7], równej $3 \mathrm{~Hz}$.

Logarytmiczny dekrement tłumienia (LDT) obliczono na podstawie wykresów drgań własnych mostu wg wzoru (3), który otrzymano poprzez odfiltrowanie wibrogramu do częstotliwości własnej.

$$
\delta=\frac{1}{n} \ln \frac{A_{1}}{A_{n}}
$$


gdzie: $A_{l}, A_{n}$ - pomierzona wartość połowy amplitudy drgań własnych odpowiednio w części początkowej i końcowej wykresu drgań,

$n$ - liczba drgań pomiędzy pomierzonymi amplitudami $A_{l}$ i $A_{n}$.

Wyznaczony z wzoru (3) logarytmiczny dekrement tłumienia przęsła wyniósł 0,283 . Wykorzystując wyznaczoną doświadczalnie wartość LDT obliczono współczynnik tłumienia ze wzoru (4):

$$
\zeta=\frac{1}{\sqrt{1+\left(\frac{2 \pi}{\delta}\right)^{2}}}
$$

Obliczony ze wzoru (4) współczynnik tłumienia dla przęsła kompozytowego wynosi 4,5\%. Wartość ta jest zbliżona do wartości otrzymanych z wyników badań trzech amerykańskich mostów kompozytowych, gdzie otrzymano minimalny współczynnik tłumienia o wartości 5\% [1]. Jest to jednak wartość znacznie niższa od wartości współczynników tłumienia mostów betonowych, które mieszczą się zwykle w przedziale 7,9-8,4\%.

\section{Podsumowanie}

Badania dynamiczne przęsła mostu wykonanego w całości z kompozytów FRP wykazały, że jego parametry dynamiczne są odpowiednie i zasadniczo spełniają aktualne krajowe wymagania, stawiane mostom drogowym. Maksymalna wartość współczynnika dynamicznego wyniosła 1,102 i jest o 13\% mniejsza od wartości projektowej. Zidentyfikowana podstawowa częstość drgań własnych wyniosła 10,1 Hz i jest ponad 3-krotnie większa od minimalnej wartości dopuszczalnej prawem, równej $3 \mathrm{~Hz}$. Jedynie tłumienie mostu jest blisko 2-krotnie mniejsze w porównaniu do np. podobnych belkowych mostów betonowych, czego jednak można było się spodziewać ze względu na małą masę konstrukcji przęsła. Jednakże nie odbiega ono zasadniczo od wartości uzyskiwanych dla innych mostów drogowych z kompozytów FRP [1].

Praca powstała w ramach projektu pn.: „Com-Bridge - Innowacyjny most drogowy $z$ kompozytów FRP”. Projekt byt realizowany $w$ ramach przedsięwzięcia pilotażowego pn.: „Wsparcie badań naukowych i prac rozwojowych $w$ skali demonstracyjnej DEMONSTRATOR+" (umowa nr UOD-DEM-1-041/001), wspótfinansowanego przez Narodowe Centrum Badań i Rozwoju.

\section{Literatura}

[1] Aluri S., Jinka C., GangaRao H.V.S.: Dynamic response of three fibre reinforced polymer composite bridges, Journal of Bridge Engineering, vol. 10, no. 6, 2005, pp. 722-730.

[2] Robinson M.J., Kosmatka J.B.: Dynamic response of a light-weight composite bridge, Proceedings of the 8th International Conference on Structural Dynamics (EURODYN'11), Leuven, Belgium, 2011, pp. 1430-1437. 
[3] Alampalli S.: Field performance of an FRP slab bridge, Composite Structures, vol. 72, no. 4, 2006, pp. 494-502.

[4] Aref A.J., Alampalli S.: Vibration characteristics of a fibre-reinforced polymer bridge superstructure, Composite Structures, vol. 52, no. 3-4, 2001, pp. 467-474.

[5] Burgueño R., Karbhari V.M., Seible F., Kolozs R.T. Experimental dynamic characterization of an FRP composite bridge superstructure assembly, Composite Structures, vol. 54, no. 4, 2001, pp. 427-444.

[6] PN-S-10030:1985. Obiekty mostowe. Obciążenia.

[7] Rozporządzenie Ministra Transportu i Gospodarki Morskiej z dnia 30 maja 2000 r. w sprawie warunków technicznych, jakim powinny odpowiadać drogowe obiekty inżynierskie i ich usytuowanie. Dz.U. 2000 nr 63 poz. 735.

\section{DYNAMIC CHARACTERISATION OF ROAD BRIDGE MADE OF FIBRE REINFORCED POLYMER COMPOSITES}

\section{S u m m a r y}

In the first decade of XXI century the new structural material, fibre reinforced polymer composites (FRP), promulgate remarkably in bridge engineering. FRP composite bridge superstructure characterizes usually the high live load / dead load ratio, which makes FRP bridges more sensitive to moving vehicles than conventional bridges. Therefore the dynamic characterization of FRP superstructure has become recently one the most important issues in its design, construction and maintenance. Dynamic characterization of a bridge is usually identified by direct measurement of accelerations, strains or displacements in relevant structural points, induced by moving vehicles with various velocities. This method has been applied in the dynamic test of the first Polish allcomposite bridge. On the basis of displacements measurement in relevant points of the FRP superstructure during bridge loading the basic dynamic parameters have been identified: dynamic coefficients, natural frequencies and damping ratio. The values established during the test confirmed the FRP composite bridge has the adequate dynamic characterization according to the Polish requirements for road bridges.

Keywords: dynamic coefficient, natural frequency, damping ratio, bridge superstructure, FRP composite, bridge test

Przestano do redakcji: 24.02.2014 r.

Przyjęto do druku: 28.04.2017 r. 